\title{
Rethinking The Rotation Term Of Reserved Seats For Women In Panchayati Raj
}

\section{Dr Nupur Tiwari ${ }^{1}$}

Senior Consultant, Union Ministry of Panchayati Raj, Government of India

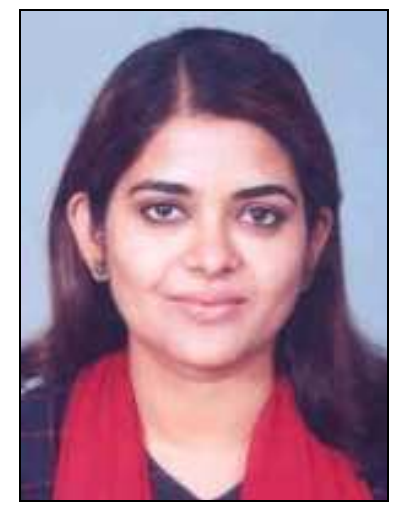

Key words: Panchayati Raj, women, elected, seats, rotation term, government

The belief that increased numbers of women holding decision-making positions is a sign of empowerment is reflected in the United Nations Gender Empowerment Measure (GEM), which tracks the percentages of women in national parliaments, in other legislatures, and as senior officials and managers among professional and technical workers. There is a growing demand for an increasing presence of women in political decision-making. It is argued that women need to be 'empowered' in the realm of political decision-making so as to facilitate their 'real' empowerment.

In India, the Women's Reservation Bill - which proposes that $33 \%$ of seats be reserved for women in both national and state legislatures - has yet to be passed. However, in local government the impact of reserving one third of seats for women in the Panchayati Raj Institutions (PRIs) ${ }^{2}$ has been immense, and has empowered women both politically

\footnotetext{
${ }^{1}$ The views expressed in the paper are those of the author and do not reflect the official policy of the organization

${ }^{2}$ Panchayati Raj Institutions (PRIs) are units of local self-government. There are three levels of panchayat - village, intermediate, and district.
} 
and socially. There are 260,000 Panchayat representatives in India, out of which 75,000 are women. This is the largest number of elected women in the world.

Whilst in general only $33 \%$ of seats are reserved for women, the State of Bihar took the bold step of reserving 50\%: currently, elected women representatives occupy 54\% of seats in Bihar's Panchayats. Bihar's example was followed by Sikkim, which increased their reservation for women to $40 \%$ and held their elections under the new arrangement in January 2008. Chhattisgarh, Madhya Pradesh, Rajasthan and Uttarakhand have passed laws increasing the reservation for women in Panchayats to 50\%. These changes will apply at the next elections to Panchayats in those States.

The Constitution (73rd and 74th Amendment) Act, 1992 sets out in detail in Article 243D, the manner in which reservations are to be provided to women and persons belonging to the Scheduled Castes (SC) and Scheduled Tribes (ST):

- Reservations to elected seats are mandated directly by the Constitution, in accordance with the following pattern:

- One-third of the total number of seats to be filled by direct election in every Panchayat are to be reserved for women. This is inclusive of the reservation provided for women belonging to the SCs and STs.

○ Within the reservation provided for persons belonging to the SCs and STs, not less than one-third of the total number of seats that are reserved for the respective categories in each Panchayat concerned are to be reserved for women belonging to the SCs and STs.

- These seats may be allotted by rotation to different constituencies within a Panchayat.

- The provisions for reservations to the offices of Chairpersons are nearly identical to the above provisions regarding reservations to elected seats. The additional features of reservations to the offices of Chairpersons are as follows:

- While providing for reservations up to a minimum level of one third in respect of women and in proportion to the population in each Panchayat for SCs and STs, the manner in which this is done is left to the legislature of a State to provide by law. 
- Unlike in the case of rotation of reservations to elected seats, which is discretionary, the rotation of reservations to offices of Chairpersons of different Panchayats is mandatory.

A recent survey, commissioned by the national Ministry of Panchayati Raj, provides many new insights into social and political empowerment of women in the new Panchayati Raj Institutions (PRIs). This is the largest-ever survey on any aspect of Panchayat functioning, covering 23 states with a total sample size of over 20,000, including Elected Women Representatives (EWRs), Elected Male Representatives (EMRs), ex-EWRs, official functionaries, and members of the community. Nearly threequarters of the EWRs in the sample belonged to the Scheduled Castes, Scheduled Tribes and Other Backward Class categories; they were evenly divided above and below the poverty line.

Reservation has played a significant role as four-fifths of all women representatives were elected from reserved seats. The role of reservation was also evident from the fact that it emerged as an important motivator (43\%) for contesting the first election, and its withdrawal was an important reason for former women representatives not contesting a subsequent election (39\%).

Thus the majority of the elected representatives had contested only one election (87\%) and only $14 \%$ had been elected more than once. Further analysis showed that the majority of former women representatives could not get re-elected because the seat to which they were elected was de-reserved in the next round. Younger women aged 21-35 years have been more successful in elections than those 35 years and above.

For most women representatives, prior association with any form of politics was limited, and the act of contesting their first election was their entry into active politics. However, a significant proportion of women representatives have said that they were earlier involved in community groups or committees, and confirmed that this helped them and motivated them to take the plunge into electoral politics. Husbands (30\%) and other family members $(12 \%)$ were reported as playing an important role in motivating women representatives to contest elections the first time. And $8 \%$ of the elected representatives mainly from West Bengal, Sikkim, Tripura and Kerala - also disclosed the role of political parties in motivating them. 
More than half (54\%) of all elected representatives were above the poverty line (APL). Little difference was observed between the economic status of male and female elected representatives. However, reservation has been critical to the representation of disadvantaged groups: 88 per cent of elected representatives from those groups were in reserved seats.

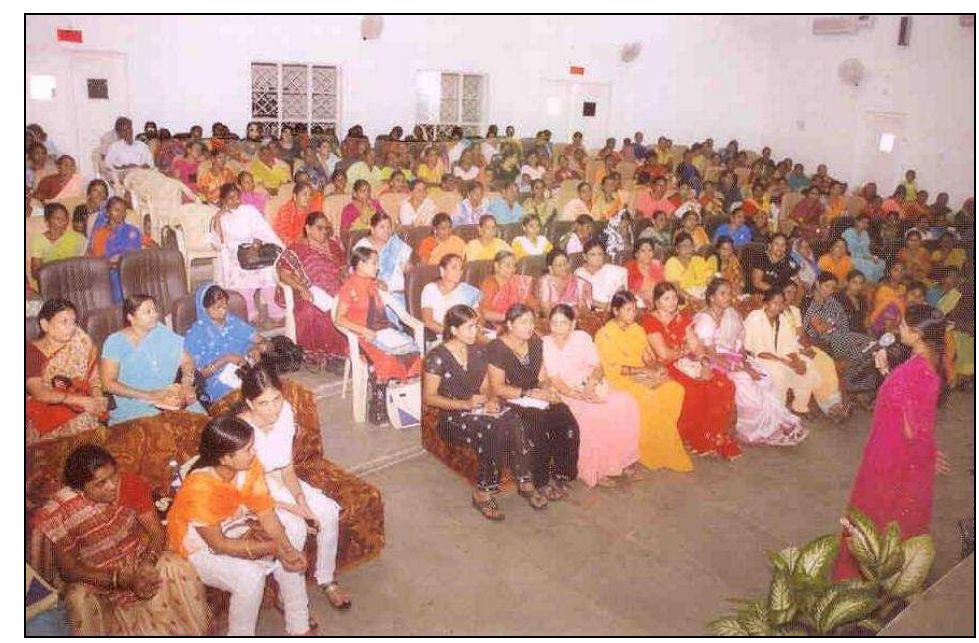

Elected Women Representatives in Chhattisgarh State Sharing their Experiences at the Panchayat Mahila Shakti Abhiyan.

Providing support for women candidates makes a big difference. In Karnataka, for instance, the government introduced a $25 \%$ reservation for women in Panchayati Raj as long ago as 1987 (which was replaced by the constitutionally mandated one third reservation in 1993). With this head start, several NGOs took the lead to undertake special capacity building programs for women elected representatives. Issues such as proxy participation and gender friendly budgets were discussed in small networks of women representatives. These networks began to grow and share their experiences amongst each other. Today, the results of this movement show that nearly $43 \%$ of seats in Panchayats are occupied by women, well above the $33 \%$ reservation. What is more remarkable is the breakdown by category: of SC elected representatives $46 \%$ are women; and of ST representatives nearly $65 \%$.

There can be no greater evidence for the fact that not only have Panchayats attracted women to politics in large numbers, but also that this wish to contest elections seems to be most keenly felt among the women belonging to the SCs and STs. 
There is, however, a big difference between representation and participation. It is relatively easy to legislate representation, but it is rather a complex and difficult task to create conditions for participation. Proper representation does not automatically lead to proper participation. It is important that women are in a position to influence decisionmaking and prepare and implement schemes for economic development and social justice.

There are many instances of women representatives playing a significant role in the workings of grassroots politics. They prioritise developmental needs differently from men. Women have initiated work on plans to bring piped water to villages and also to build schools. They are also seen to be more involved in monitoring the presence of teachers and medical staff in the school or health centre, and inspecting nutrition centres under the Integrated Child Development Scheme.

Women have taken the lead in making efforts for smokeless stoves, crèches and community halls, and have taken the initiative in family and matrimonial matters, for example counselling abusive and/or alcoholic husbands. Sometimes, women-led Panchayats have even experienced a dramatic increase in their revenues, sponsoring the auction of village ponds, community forests and village markets for the larger welfare of the community (Jayal 2006).

A women's representative in Dahod district in Gujarat said that she had proposed setting up a primary school in the village, but was told there was no necessity for it because there were only three children whose parents wanted it. She set about mobilising support for the school, which was later established, and came to be attended by 300 children. Attendance was at least partly achieved through stiff penalties for non-compliance: a fine of Rs. 600 and 6 months in prison for the parents of those children who do not attend. It is notable that until elected to the Panchayat, this woman had not stepped out of the boundaries of her home, or even been a member of any other organization.

However, women representatives remain largely excluded from discussion of some issues, such as planning for rural development works. While no gender discrimination in the Panchayat is reported by $60 \%$ of elected women representatives, issues concerning their acceptance in Panchayat meetings and enabling them to raise issues freely were mentioned by $94 \%$. 
Successful women representatives now act as role models for others. Their increased presence has ensured the principles of justice between the sexes, and has certainly led to the fulfillment of certain interests of women which otherwise may be neglected. A majority of the representatives report an enhancement in their personal effectiveness and image after being elected. They also report a reduction in household responsibilities.

It is for sure that without the system of reservation women would have had little role to play in grassroots politics in India. Surveys show that $95 \%$ of women representatives claimed they would never come to acquire positions in Panchayats, if there were no reserved seats (Centre for Women's Development Studies 1999). Reservation has at least succeeded in bringing the womenfolk of rural India into the political forum, and elected women could now imagine standing against a man in future.

Women members of Panchayats are gradually learning to adjust to the new political conditions. The political knowledge of women is increasing and gradually a sense of confidence is getting instilled in them, as they are now aware of the problems being faced by their locality. By all accounts, as each election round passes, it is clear that women have certainly made their presence felt in the power struggles once dominated by men. There are many instances where women have been self-motivated to fight an election. In several instances, the Gram Sabha ${ }^{3}$ has persuaded women with leadership potential to stand for election, and this has a far-reaching impact on the empowerment of women.

Patriarchy is not reversed, or even significantly eroded, overnight. Nevertheless, there are across India many shining examples of the potential of women's leadership, and many more may join their ranks if at least the institutional conditions for their effective participation are safeguarded. Within this larger process, the debate over the system of reservation for women in Panchayats is extremely critical. In several States proposals are being considered to slow the rotation of reserved seats from once every five years to a rotation every two or more terms. This follows the example of Tamil Nadu and gives women who are elected to a reserved seat the opportunity to stand for election for a second term in the same seat.

\footnotetext{
${ }^{3}$ A bi-annual village meeting of all persons aged 18 years or more, which considers development schemes and reviews the work of the Panchayat.
} 
The Union Minister of Panchayati Raj, Shri Mani Shankar Aiyar has argued that: "the rotation term of reserved posts for women should be extended up to two or three terms because generally first term for women representatives has proved to be a period of learning and in second and third term only women representatives started showing their real performance."

Extending the rotation term of reserved positions for women in this way would allow women in Panchayats the time and space to negotiate their own power relationships within them. If they are given 10 to 15 years of continued opportunity, it can encourage and nurture their desire to be assertive and independent. Without a longer term, true empowerment of women representatives will be a more difficult proposition.

\section{References}

Centre for Women's Development Studies 1999, From Oppression to Assertion: A Study of Panchayats and Women in M.P., Rajasthan, and U.P., CWDS, New Delhi.

Jayal, Niraja Gopal 2006, 'Engendering Local Democracy: The Impact of Quotas for Women in India's Panchayats', in Democratization Vol. 13, No. 1, February, pp.15-35.

Ministry of Panchayati Raj 2008, Study on Elected Women Representatives in Panchayati Raj Institutions: Report, Government of India, India. 